\author{
Monika Pasternak-Malicka \\ The Rzeszow University of Technology \\ Faculty of Management \\ e-mail: malicka@prz.edu.pl \\ ORCID: 0000-0002-0011-7626
}

\title{
THE LENGTH OF MATERNITY LEAVE AND ITS STATUTORY PAY AS A DETERMINANT OF WOMEN'S PROFESSIONAL ACTIVITY
}

DOI: $10.15611 /$ pn.2020.12.05

JEL Classification: H23, H31, H50, J13, J16, J21

(C) 2020 Monika Pasternak-Malicka

This work is licensed under the Creative Commons Attribution-ShareAlike 4.0 International License. To view a copy of this license, visit http://creativecommons.org/licenses/by-sa/4.0/

Quote as: Pasternak-Malicka, M. (2020). The length of maternity leave and its statutory pay as a determinant of women's professional activity. Prace Naukowe Uniwersytetu Ekonomicznego we Wrocławiu, 64(12).

\begin{abstract}
The purpose of the paper is an attempt to assess the impact of the length of maternity leave as the basis for the payment of maternity allowance under social insurance and its statutory pay on the professional activity of women. The paper evaluates the relationship between the length of maternity leave and related payments of maternity allowance and the employment rate, and also tries to indicate whether extending maternity leave may limit women's employment. The paper describes the professional activity of women, and the level of expenditure on childcare related benefits in Poland and in selected European Union countries. Based on statistical data, an attempt was made to assess the impact of maternity benefits on the economic activity of women based on the linear regression method. Some parts of the author's own surveys from 2013-2020 were also presented. They suggest that extending maternity leave may discourage employers from taking on women and, consequently, lead to their withdrawal from the labour market.
\end{abstract}

Keywords: public finance, maternity allowance, maternity leave, economic activity rate of women

\section{Introduction}

The role of social insurance is to ensure social security for people who, due to random events specified in law, cannot actively carry out tasks related to their professional work. The aim of the paper is an attempt to assess the impact of the length of maternity 
leave as the basis for the payment of maternity allowance and its statutory pay on the economic activity of women. The paper attempts to assess the relationship between the level of maternity allowance expenditure and the employment rate, and based on the surveys carried out, to indicate whether extending maternity leave may reduce the economic activity of women or discourage employers from hiring them.

The implementation of this goal required the use of descriptive and statistical methods, in particular the linear regression method. The direct questionnaire method was also used. The author adopted the research hypothesis that the length of maternity leave and the related payment of maternity benefits affect women's professional activity. Due to editorial restrictions, the impact of other factors that may have an influence on the labour market was omitted, and attention was drawn only to the relationship between state support after childbirth and women's economic activity.

The first section describes the professional activity of women in Poland and the European Union. The next presents the essence of leave and maternity allowance as a cash benefit paid from social security under sickness insurance. Based on statistical data, an attempt was made to assess the impact of extending maternity leave on women's professional activity based on the linear regression method. Some parts of the author's own surveys from 2013-2020 are also presented.

\section{Professional activity of women in the subject literature}

The transformation of the modern world related to the globalization process has significantly increased the professional activity of women. When analyzing the literature on the subject, it can be concluded that the theoretical analysis of women's functioning in the labour market is an extremely difficult task. Most of the theoretical concepts in the field of sociology, psychology and economics do not take into account the specificity of the social roles that have always been assigned to women. One concept that refers to the role of the family and tries to explain the current state of affairs is that of Talcott Parsons (Turner, 2012). According to Leski, along with industrialization, new opportunities have opened up for women who should not be treated only as dependent on men (Pufal-Struzik, 2017). Currently, the phenomenon of the permanent presence of women in the labour market is considered as a new, increasingly important structural feature of modern society (Domański, 2004, pp. 34-35).

The level of professional activity of women depends on many economic and social factors, as well as cultural and religious premise. In most developing countries, women are potentially a disadvantaged group in the labour market. More often than men they are exposed to extreme poverty, are less educated, have less access to modern technologies, and also face formal barriers when they wish to enter the labour market. The development of modern technologies can become a factor 
that stimulates social and economic changes. At present, in spite of the improvement of the situation in the period 1990-2017 in the level of education and access to ICT, it is difficult to state unequivocally whether the implementation of information and communication technologies had a direct impact on the economic activity of women and the amount of their remuneration (Lechman, 2019). The currently introduced employment and anti-unemployment policies are implemented based on the principle of counteracting gender discrimination in the labour market and equalizing opportunities (Doorne Huiskes, 2003).

In most European countries, for more than two decades in the field of employment policy and the labour market, the emphasis has been put on the continuous improvement of women's professional activity, which will also depend on the situation in the labour market (Raišiena, Bagdonienb, \& Bilan, 2014). The greater supply of employment will then translate into the greater professional involvement of women. The number of jobs is affected, among others, by GDP growth. It was shown that a $1 \%$ increase in GDP reduced the unemployment rate by $0.08 \%$ (Soylu, Çakmak, \& Okur, 2018). At the same time, providing entrepreneurs with a higher degree of flexibility and responsiveness, as well as attracting foreign investors to the country will create the premise for decreasing unemployment and create new jobs in the regions of South East Europe (Qerimi \& Sergi, 2017).

The professional activity of women in Poland is steadily increasing (Sielska, 2017, pp. 58-84). This is due to market transformations (Greene, Hart, Gatewood, Brush, \& Carter, 2003), changes in life preferences, an increase in the level of women's education and the transformation of the pension system, where the accumulated capital determines the amount of the pension (Dijkstra \& Plantega, 2003; Gilligan, 1982; Titkow, 2003). Women are also characterized by greater work flexibility (Abrhám, Bilan, Krauchenia, \& Strielkowski, 2015). At the same time, the level of professional activity of women is strongly determined by the settling of their children, and along with the increase in the number of children, the level of professional activity of women decreases (Dahlstrand \& Politis, 2013; Duberley \& Carrigan, 2013).

Research indicates that the negative impact of social benefits that can discourage work is visible (Pal'ová \& Vejačka, 2018, pp. 96-112). The impact of social benefits will depend on the socio-economic policy adopted in the country and the social awareness. In Greece, where "welfare is a state idea", the implemented social payment system discourages employment. The opposite can be Germany, where conservative policy promotes professional activity (Cohen, 2017).

\section{Professional activity of women in Poland and selected countries}

Women make up half of the world's population, but only $50 \%$ of them aged 15 and over are professionally active, while for men it is $77 \%$ (United Nations, 2015). 
The level of women's activity in individual EU countries is presented in Figure 1. In 2019, in the countries analysed, the highest level of women's employment was recorded in Lithuania (77.4\%), Germany (76.6\%), and Denmark $(73.9 \%)$, The Netherlands (75.5\%) and Finland (75.8\%). The average for 28 countries was $67.4 \%$ in 2018, while for 27 countries it was $67.3 \%$ in 2019 .

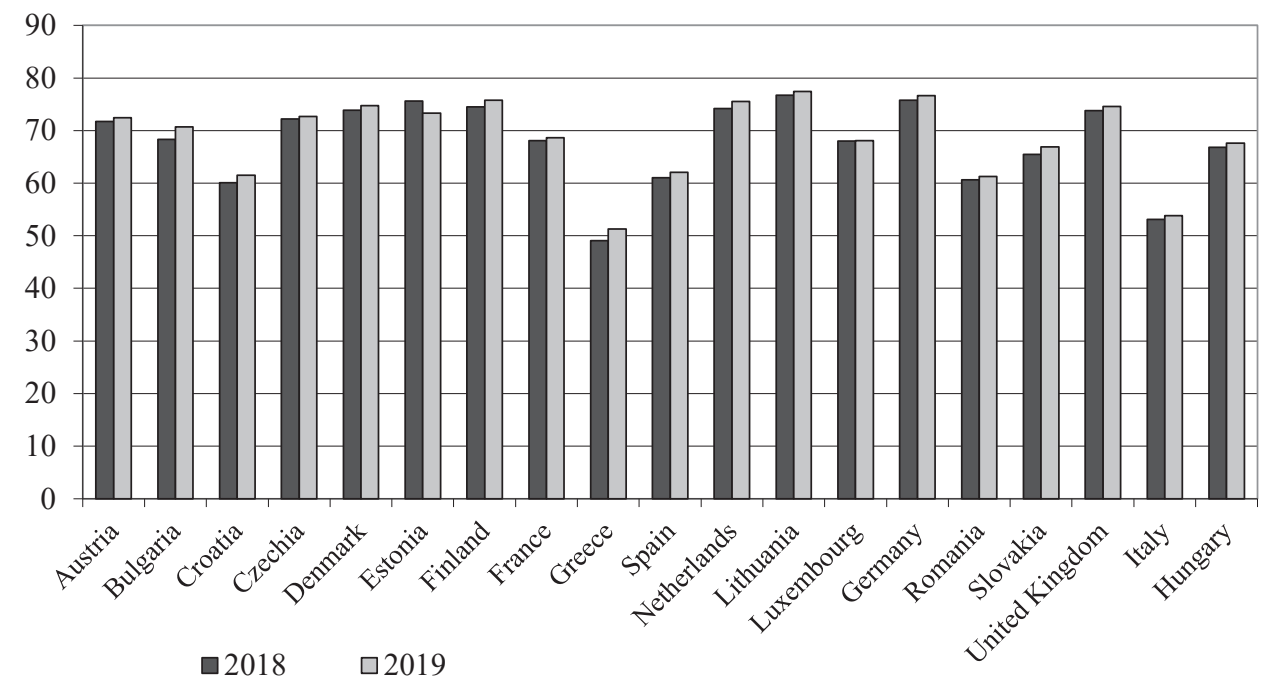

Fig. 1. Women's participation rate in selected EU countries in 2018-2019 (in \%)

Source: own study based on (Eurostat, 2020).

In contrast, the lowest percentage of working women aged 20 to 64 was observed in Greece (51.3\%), Italy (53.8\%), Croatia (61.5\%) and Spain (62.1\% ). The participation rate of women in Poland is one of the lowest in the EU.

Figures 2 and 3 present the situation in the labour market in Poland in the period 1999-2020 according to gender. Significant differences in the level of employment of women and men are visible over selected years. The CSO statistics show that the recent economic activity of women slightly increased to $48.0 \%$ in $2017-2019$, nevertheless the intensity of men's professional activity is on average a dozen or so percent higher in the period analysed. The lowest level of the economic activity rate of women was in 2006-2007, when it was 46.7\%.

Figure 4 shows the economic activity rate for women aged 25-29, which was the lowest in the third quarter of 2017 (Q4 2019 was 73.5\% and showed a downward trend compared to the last quarter of 2018) (GUS, 2020a). Women aged 30-34 were characterized by greater professional activity, but also seasonal fluctuations, characteristic of the Polish labour market were visible (Q1 2019-7.3\%, Q1 2020 - 
76.7\%). After the introduction of the Family 500+ benefit in April 2016, a downward trend can also be observed in relation to women aged 25-29 (Q1 $2019-77.3 \%$, Q4 $2019-75.2 \%$, Q1 $2020-70.6 \%)$.

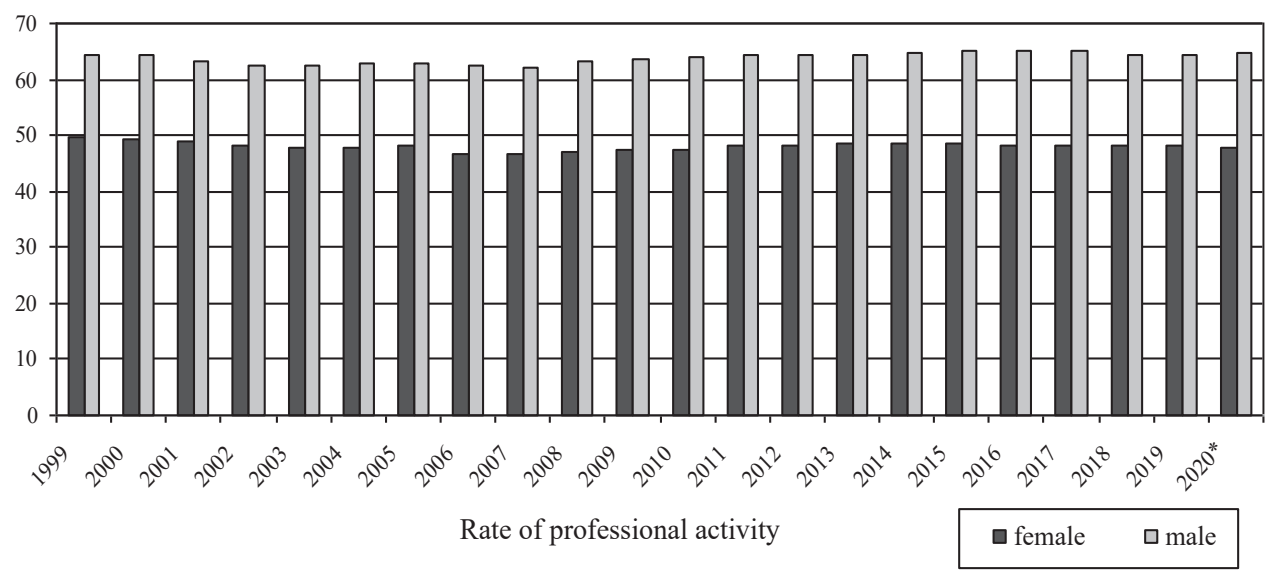

*Q1 2020

Fig. 2. Activity rate by gender in Poland in 1999-2020 based on LFS (in\%)

Source: own study based on (GUS, 2004; GUS, 2018a; GUS, 2019, p. 69, p. 112).

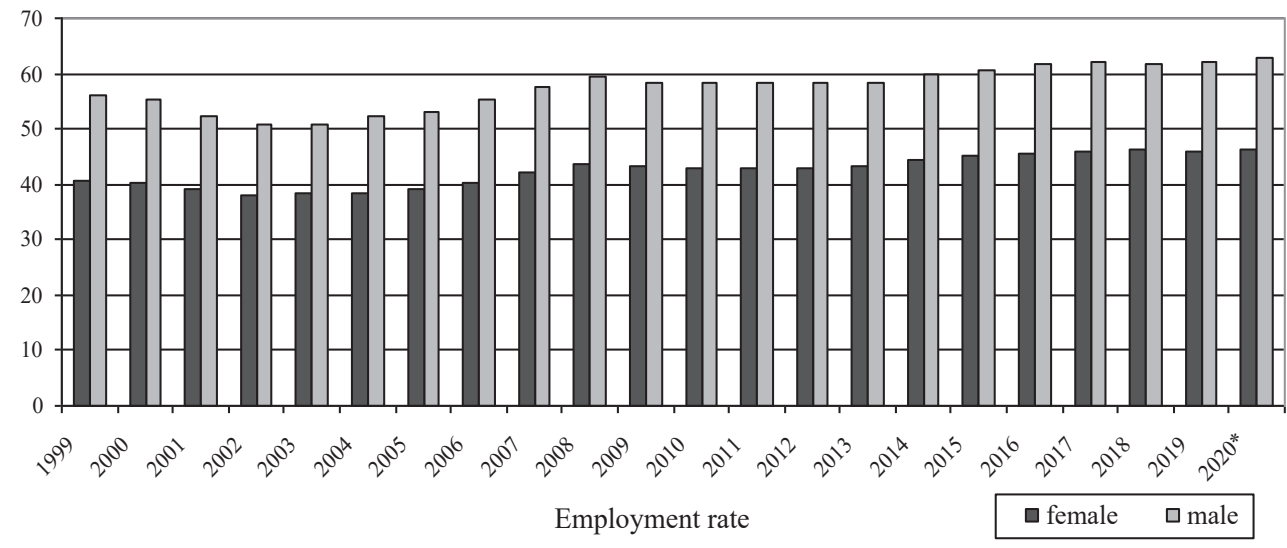

*Q1 2020

Fig. 3. Employment rate by gender in Poland in 1999-2020 based on LFS (in \%)

Source: as in Figure 2. 


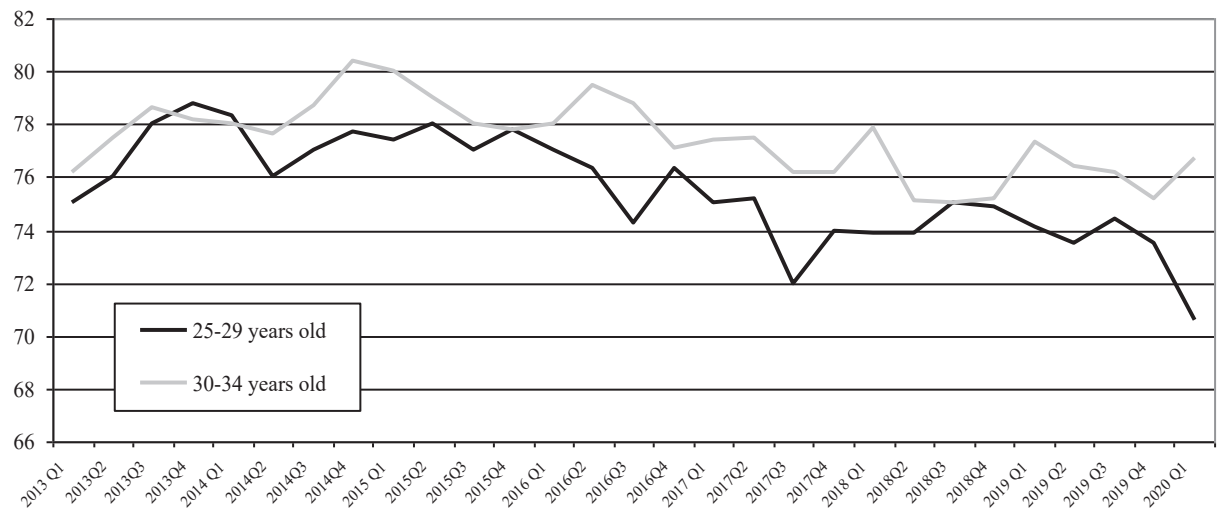

Fig. 4. The economic activity rate of women aged 25-34 in Poland in 2013-2020

Source: (GUS, 2020b)

\section{Maternity leave in Poland and selected countries}

Maternity leave, under which maternity allowance is paid, is defined as an unconditional, mandatory dismissal in connection with giving birth to a child (Kwiatkowska, 2016, p. 58). Maternity allowance, on the other hand, is a cash benefit financed from the Social Insurance Fund, which is granted to replace income lost as a result of abstaining from work due to childbirth and the obligation to care for it in person during the first months of life (Biernat \& Gronek, 2018, p. 40).

In recent years, there have been numerous changes regarding the length of maternity leave and related payments for maternity allowance. The amount of leave for the birth of one child was 16 weeks (112 days) until 1999 and in the years 2002 2005. Since 2010, two new leaves related to the birth of a child have been introduced - an additional leave ( 20 weeks) and paternity leave ( 7 days). The latter was extended to 14 days in 2012. In 2013, an additional 26-week leave called parental leave was introduced to the existing solutions related to personal childcare.

Further legal changes took place in January 2016. From the moment of their introduction, two types of leave related to birth of a child apply: maternity leave of 20 weeks (140 days) and parental leave of 32 weeks (224 days). Maternity allowance for paternity leave is granted to the father of a child of 14 days.

Maternity allowance paid for the period of maternity leave and paternity leave (there is no separate paternity benefit) is granted in the amount of $100 \%$ of the calculation basis (current remuneration), while for the period determined as the period of parental leave - in the amount of $60 \%$ of the calculation basis. A parent who immediately chooses the so-called annual maternity leave receives an allowance of $80 \%$ throughout the period. 


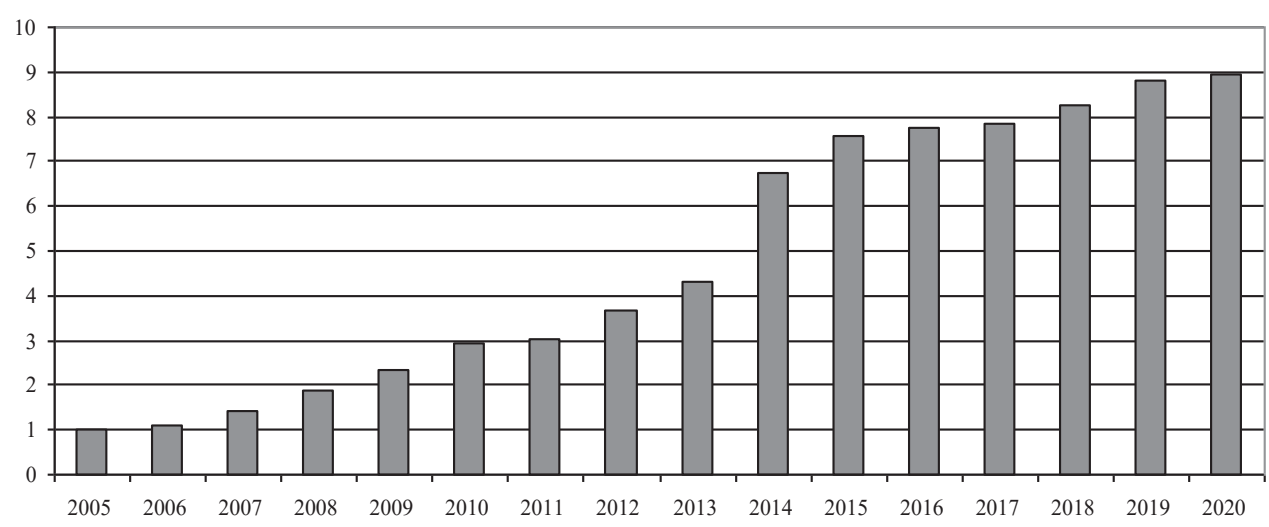

Fig. 5. Amount of paid-out maternity benefits in 2005-2020 (in PLN billion)

Source: own study based on (Korpas, 2018, pp. 87-103; ZUS, 2019, p. 26).

As a result of these changes, payments for maternity benefits have increased significantly. Figure 5 presents the amount of payment of maternity benefits in Poland in the period 2002-2020. Initially, the value of payments fluctuated around one billion PLN in 2005, while in 2013-2014 a sharp increase in payments was visible as a result of introducing parental leave and extending maternity leave. In 2017 the total amount of benefits paid was PLN 7863570 including: PLN 3403463 for maternity leave, PLN 28853 for additional maternity leave, PLN 4055542 as part of parental leave benefits and PLN 282238 for paternity leave.

In 2018, 527,410 women and 210,364 men received the allowance - including maternity leave (415,462 women and 4,426 men) (ZUS, 2019). The average monthly number of beneficiaries was 738 thousand. The total amount of payments under the maternity allowance reached PLN 8.26 billion in 2018 .

Maternity allowances are paid by the Social Insurance Fund under sickness insurance and constitute an important item in the expenses incurred by the SIF Sickness Fund. According to the plan, in 2020 these were to amount to PLN 8940354 , which constitutes 36.46\% of expenditure on the Sickness Fund (Fundusz Ubezpieczeń Społecznych, 2020).

In most countries, maternity allowance is paid by national social security institutions directly or through the employer. The duration of maternity leave and the amount of the benefit vary, although there are obligatory periods in most countries (usually six weeks, eight in Poland), although obligatory maternity leave does not exist in the USA and Russia, for instance.

Maternity leave in France is divided into prenatal (from 6-24 weeks) and postprenatal (from 10 to 24 weeks). It is granted for one year with the option of renewing it twice and depends on the number of children that were already born and are about to be born. The minimum lengths are 6 weeks before and 10 weeks after the birth of 
the first two children. In the case of giving birth to the third child, its length increases by 2 weeks before and 8 weeks after delivery. Fathers are entitled to 10 days paternity leave. Maternity allowance is paid in the amount of $100 \%$ of the current earnings (Centrum Analiz Fundacji Republikańskiej, 2012; Raport PwC, 2016).

In Great Britain, childbirth leave (Statutory Maternity Pay SMP) is granted to women who have worked for at least 26 weeks for the given employer for up to 15 weeks before giving birth. The length of the leave is 52 weeks, of which 39 weeks are payable. For the first 6 weeks the employer pays $90 \%$ of the weekly salary, and over the next 33 weeks $90 \%$ of the weekly salary, or around 200 euros per week.

In Germany, every woman employed under a contract of employment is entitled to a 14-week maternity leave, of which 6 weeks are possible before delivery, and 8 weeks after childbirth. In the case of a twin pregnancy, the duration of leave is extended by 4 weeks. Maternity leave is fully paid and financed mainly by the employer. Parental leave is granted after maternity leave and lasts up to three years.

The Hungarian maternity leave system allows one parent to look after children even until they are 10 years old (in the case of disability). The standard maternity leave is 24 weeks, of which 4 weeks can be used before delivery. Women who receive social security payments (full-time employment or business activity) are entitled to receive it for at least one year within two years before the child's birth. The allowance is $70 \%$ of the earnings.

\section{The impact of amounts of maternity benefits on women's professional activity}

The paper uses the linear regression method (method of estimating the expected value of a variable) to examine whether there is a statistical relationship between the amount of maternity benefits paid and the economic activity of women. Figure 6 presents a scatter chart, which is a graphic interpretation of the correlation between the female rate of participation and the amount of maternity allowance payments in Poland in 2005-2019. The analysis shows that in this case there is no statistical relationship between the two variables.

Figure 7 was prepared on the basis of the economic activity coefficient of women aged 25-29 in relation to the length of maternity benefits. In this case, the determination index was 0.6541 , which means a satisfactory match of both variables. The chart shows a negative correlation, which may indicate that an increase in the length of maternity benefits will result in a decline in the economic activity of women at the age with the highest birth rate. Figure 8 , on the other hand, illustrates the dispersion graph between the length of maternity leave and the employment rate of women in Poland in 2005-2019. R2 was 0.5846, which is a poor statistical fit. 


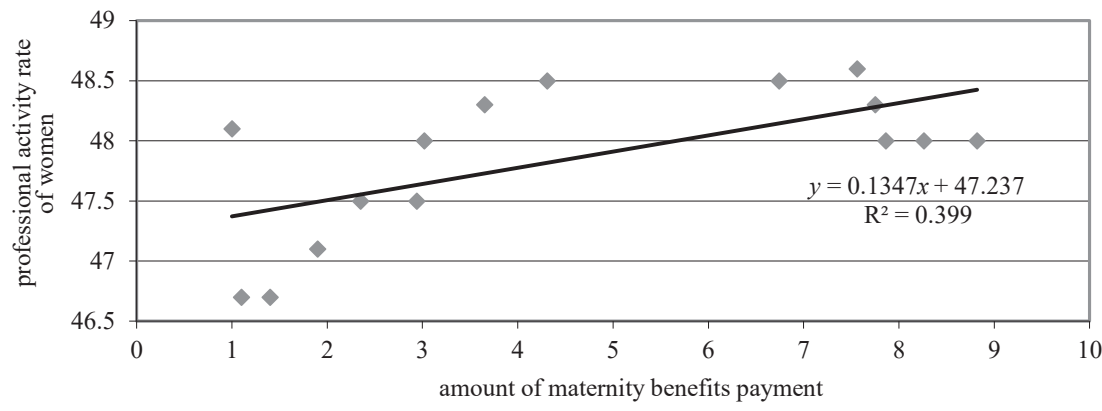

Fig. 6. Scatter chart between the amount of maternity allowance payments and the economic activity rate of women in 2005-2019 in Poland

Source: own study based on Figures 3 and 5.

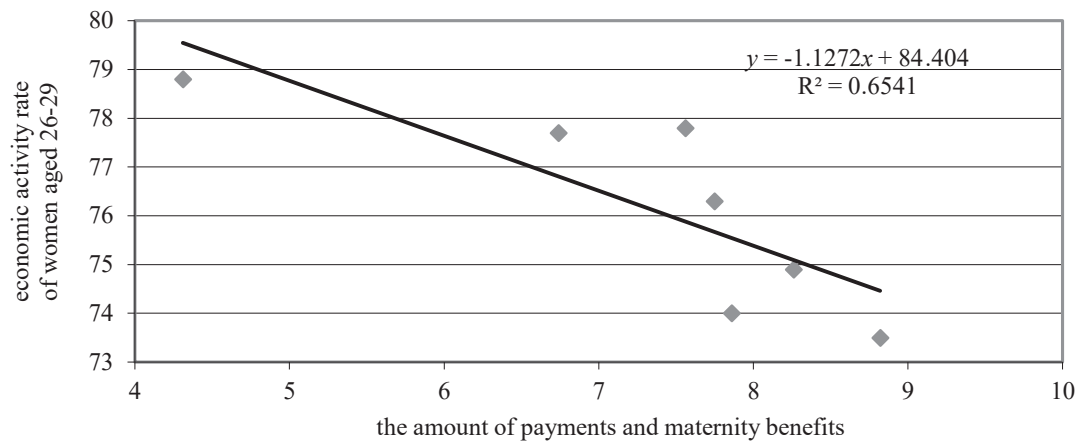

Fig. 7. Scatter chart between the amount of maternity benefits and the economic activity rate of women aged 25-29 in Poland in 2013-2019

Source: own study based on Figures 4 and 5 .

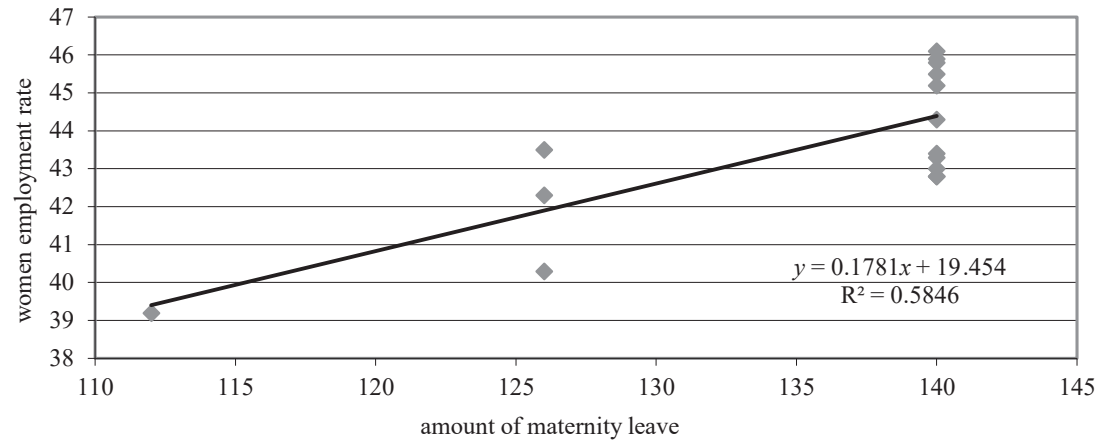

Fig. 8. Scatter chart between the maternity leave dimension and the employment rate of women in Poland in 2005-2019

Source: own study based on Figure 2 and (ZUS, 2019). 


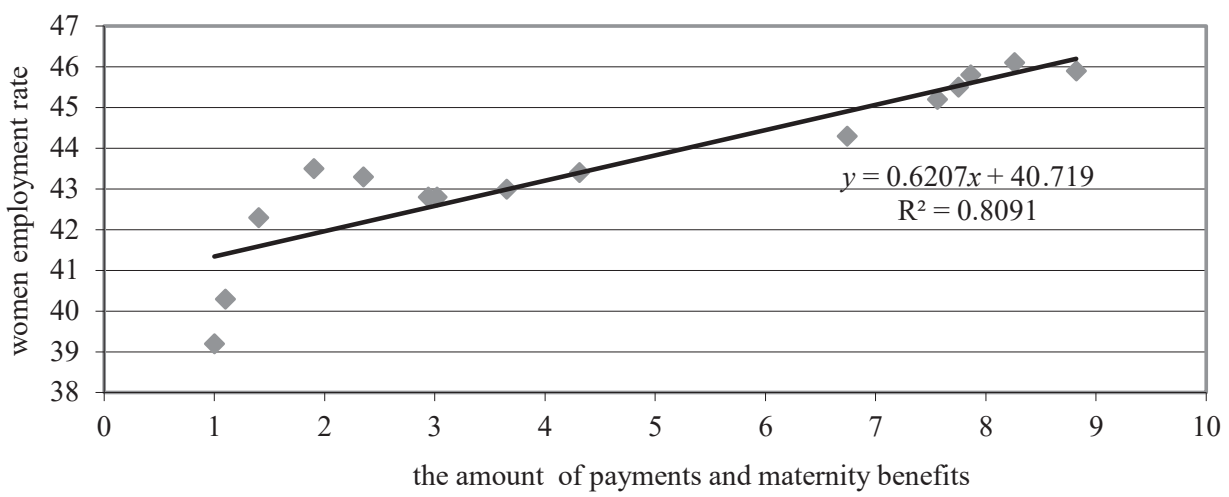

Fig. 9. Scatter chart between the amount of maternity benefits payments and the employment rate for women in Poland in 2005-2019

Source: own study based on Figures 2 and 5.

Figure 9 shows the relationship between the level of maternity allowance expenditure and the employment rate for women in Poland in 2005-2019. Using the linear regression method, the formula of the regression equation was determined, which is located in the upper right corner of the chart. Below it there is the $\mathrm{R}^{2}$ factor, i.e. the indicator of determination whose value was 0.8091, which means a good match of both variables. The chart also shows a positive correlation, which may prove that an increase in spending on family benefits will increase the employment rate among women. Perhaps this is due to the fact that home budget support with maternity benefit is determined by the requirement to have a job. In addition, the increase in the economic activity of women at the end of the second decade of this century coincided with the good economic situation, the emergence of many jobs and increasingly flexible forms of employment enabling to reconcile maternity and professional responsibilities. At the same time, maternity and parental leave increased significantly during this period.

\section{The length of maternity leave and the professional activity of women in empirical research}

In 2013, pursuant to the amendment to the Labour Code, a new type of leave i.e. parental leave (182 days) was introduced, while additional maternity leave was extended by another 14 days. However, since 2016 the leave related to the birth of a child consists of 20 weeks maternity leave and 32 weeks parental leave. The allowance, regardless of the type of leave, is called maternity allowance. The new solution allows mothers to be on paid leave for 52 weeks, hence it is colloquially referred to as annual maternity leave. 
As part of the author's own research from 2013-20201, households and entrepreneurs were asked about the effects of extending maternity leave. Figures 10 and 11 present the structure of the responses of households and economic entities to this question. The respondents most often pointed to the visible reluctance of employers when employing women - in fact nearly every third respondent.

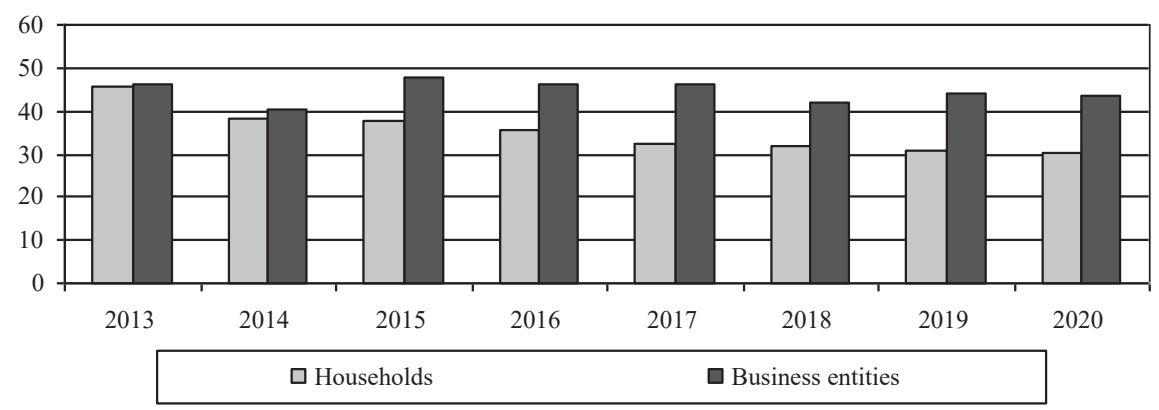

Fig. 10. Structure of answers to the question whether the result of extending maternity leave will be the reluctance to employ women

Source: own calculations based on data from a survey of households and business entities for 2013-2020.

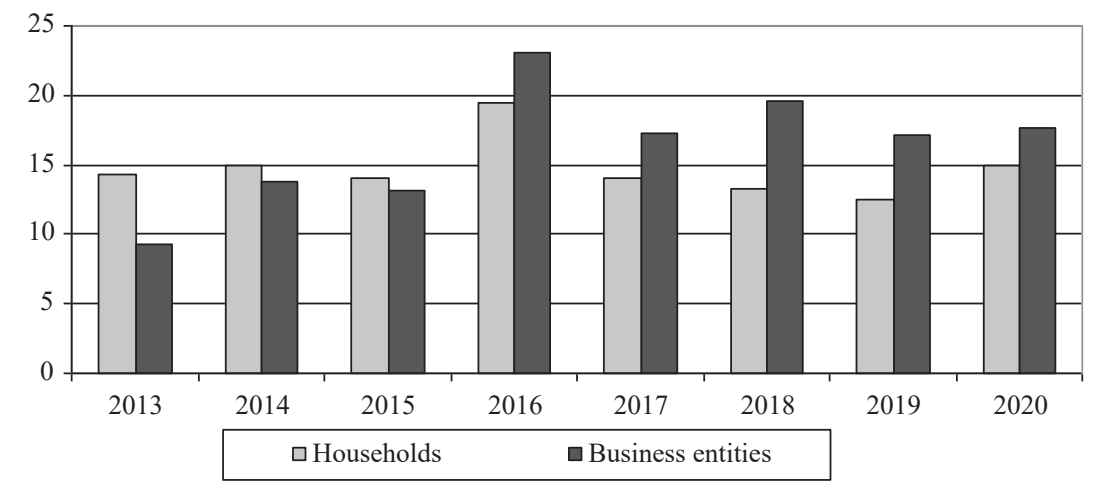

Fig. 11. Structure of answers to the question whether the extension of maternity leave will not affect the employment of women

Source: own calculations based on data from a survey of households and business entities for 2013-2020.

${ }^{1}$ The author's own research was conducted on a targeted sample of 1128 households and 237 business entities (in January 2013); 857 households and 188 business entities (in January 2014); 852 households and 224 business entities (in January 2015); 1,103 households and 325 economic entities (in January 2016), 883 households 1,038 households and 289 economic entities (in January 2017), 883 households and 225 companies (in January 2018), and 975 households and 268 companies (in January 2019). This is a continuation of surveys initiated in May 2007 and repeated annually. The interviews in 2013-2020 were conducted in Podkarpackie Province. The surveys were directed to people aged over 20 with different levels of income and standard of living. 
In the case of entrepreneurs, the reluctance to employ women was emphasized even more (43.8\% in 2020), as well as the hindering of professional advancement (21.5\% in 2020). Only every tenth employer in the last year of the study noticed the positive effects of the introduced change for bringing up children.

In national surveys carried out after extending maternity leave from 20 to 22 weeks in $2011,45 \%$ of the companies surveyed planned to increase employment, but only $36 \%$ took into account the employment of mothers (a year earlier this ratio was 45\%, cf. Baranowska-Skimina, 2011). According to research from 2013 by Rękas, among women in managerial positions, none of the respondents took full maternity leave, and $69.2 \%$ did not take any leave at all. Among the main reasons for the quick return to work, $82.7 \%$ of respondents indicated the fear of losing their jobs and positions in the event of a long absence (Rękas, 2013).

The decrease in women's economic activity after extending the duration of maternity leave is the subject of several scientific studies. The research conducted in European countries indicates that a too-long leave related to childcare negatively affects the economic activity of women, as well as their probability of returning to work afterwards (Rhum, 1998; Thevenon \& Solaz, 2013). It is difficult to estimate the optimal length of maternity leave with the most positive impact on women's employment. The research does not show an unambiguous answer - the optimal dimension of leave ranges from six (Akgunduz \& Plantenga, 2013) to twenty weeks (Jaumotte, 2003).

In Poland, there is a widespread belief ( $89 \%$ of respondents) that a mother should look after her small child and if she cannot combine these two obligations, she should leave her job. Thus in Poland, the care of a small child is considered only to be the domain of women, which may mean that women are discriminated against in the labour market. In the first decade of this century as many as $23 \%$ of women declared that they are not employed because they are not able to combine professional work with family responsibilities (Kotowska, Sztanderska, \& Wóycicka, 2007, pp. 4-7). Thus, extending maternity leave can help young women maintain their jobs.

\section{Conclusions}

Maternity leave, in line with EU policies, is gradually being extended in most countries. The main justification for extending the period of paid leave to take care of a child is to enable the fulfillment of family obligations and to facilitate the return to work after childbirth. Since the maternity leave should not be determined by the material conditions of the family, therefore the maternity leave is obligatorily compensated in the amount of $80 \%-100 \%$ of the remuneration for work.

These decisions can be analyzed both in the context of the positive effects (improving the quality of childcare, guaranteeing employment in the perinatal period), as well as the negative consequences (effects on women's activity in the labour market, unwillingness of employers to employ them). 
The hypothesis set out at the beginning that the maternity leave period and the related payment of maternity benefits affect the economic activity of women, seems to be confirmed by the test results and the analyses published. The professional activity of young women in Poland aged 25-29 and 30-34 shows a downward trend compared to the period before the introduction of the one-year maternity leave". The surveys indicate that one of the effects of extending the leave related to childbirth may be the difficulties for women in finding a job (every third household and nearly half of entrepreneurs indicated a reluctance to employ women).

However, the interpretation is not so obvious. Based on the linear regression method, it was pointed out that an increase in family allowance expenditure has a positive effect on the increase in the employment rate among women. Perhaps this is due to the fact that supporting the household budget with maternity allowance is connected with the necessity of employment. In addition, the increase in the economic activity of women in the period analysed coincided with the good economic situation, the emergence of many jobs and increasingly flexible forms of employment enabling to reconcile maternity and professional obligations. At the same time, there was a significant extension of maternity and parental leave.

It seems that the extension of paid maternity leave to a certain point may have a positive effect in the form of a greater tendency of women to engage in work, in particular those planning to give birth in the future. On the other hand, the demand for working women may be reduced due to the fact that an employer, when deciding to employ a young woman, is exposed to greater risk and potentially higher non-wage labour costs. Even in a situation where entrepreneurs do not bear the cost of maternity benefits directly, they are forced to make organizational changes in the functioning of their companies due to the statutory protection of the employment relationship.

\section{References}

Abrhám, J., Bilan, Y., Krauchenia, A., \& Strielkowski W. (2015). Planning horizon in labour supply of Belarusian small entrepreneurs. Economic Research-Ekonomska Istraživanja, 28(1), 773-787. Retrieved from http://dx.doi.org/10.1080/1331677X.2015.1084238

Akgunduz, Y. E., \& Plantenga, J. (2013). Labour market effects of parental leave in Europe. Cambridge Journal of Economics, 37(4), 845-862.

Baranowska-Skimina, A. (2011). Spadajace szanse pracujacych matek - wyniki raportu 2011. Retrieved from http://www.egospodrka.pl/61266,Spadaja-szanse-pracujacych-matek,1,39,1.html

Biernat, P., \& Gronek, E. (2018). Zasiłek macierzyński i opiekuńczy jako świadczenia pieniężne wypłacane z ubezpieczeń społecznych w ramach ubezpieczenia chorobowego. Rynek-Społeczeństwo-Kultura", 2(28).

Centrum Analiz Fundacji Republikańskiej. (2012). Polityka prorodzinna w wybranych krajach Unii Europejskiej, Warszawa: Centrum Analiz Fundacji Republikańskiej, 5-32.

Cohen, E. (2017). Effect of welfare and employment policies on the correlation between migration and unemployment. Economics and Sociology, 10(1), 246-264. doi:10.14254/2071-789X.2017/10-1/18

Dahlstrand, A. L., \& Politis, D. (2013). Women business ventures in Swedish university incubators. International Journal of Gender and Entrepreneurship, 5(1), 78-96. doi:org/10.1108/17566261311305229 
Dijkstra, A. G., \& Plantega, J. (2003). Ekonomia i płeć. Gdańsk: Gdańskie Wydawnictwo Psychologiczne.

Domański, H. (2004). Struktura społeczna. Warszawa: Wyd. Naukowe SCHOLAR.

Doorne Huiskes von, A. (2003). Równe szanse w Unii Europejskiej: teoria i praktyka. In A. G. Dijstra, \& J. Plantenga (Eds.), Ekonomia i pteć. Pozycja zawodowa kobiet w Unii Europejskiej. Gdańsk: GWP.

Duberley, J., \& Carrigan, M. (2013). The career identities of 'mumpreneurs': Women's experiences of combining enterprise and motherhood. International Small Business Journal, 31(6), 629-651. doi: $10.1177 / 026624261143518$

Eurostat. (2008). Reduced gap in employment rates between men and women in the EU27 (No. 158/2008, 13 November). Retrieved from ec.europe.eu

Eurostat. (2018). Employment rate of people aged 20 to 64 in the EU in 2017 (No. 68/2018, 20 April, p. 4). Retrieved from ec.europe.eu/Eurostat

Eurostat (2020, April). Employment Statistics in 2019. Retrieved from https://ec.europa.eu/eurostat/ statistics-explained/index.php/Employment_statistics/pl

Fundusz Ubezpieczeń Społecznych. (2020). Fundusz chorobowy - plan na 2020 r. Warszawa. Retrieved from https://www.zus.pl

Gilligan, C. (1982). In a different voice: Psychological theory and women's development. Cambridge, MA: Harvard University Press.

Greene, P. G., Hart, M. M., Gatewood, E. J., Brush, C. G., \& Carter, N. M. (2003). Women entrepreneurs: Moving front and center: An overview of research and theory. Retrieved from http://www. unm.edu/ asalazar/Kauffman/Entrep_research/e_women.pdf

GUS. (2004). Kobiety i mężczyźni na rynku pracy 2004. Warszawa: GUS. Retrieved from www. stat.gov.pl

GUS. (2017). Sytuacja kobiet i mężczyzn na rynku pracy 2016. Warszawa: GUS. Retrieved from www. stat.gov.pl

GUS. (2018a). Kwartalna informacja o rynku pracy w czwartym kwartale 2017 roku. Warszawa: GUS.

GUS. (2018b). Świadczenia na rzecz rodziny w 2017 r. Warszawa: GUS.

GUS. (2019). Aktywność ekonomiczna ludności Polski I kwartał 2019 r. Warszawa: GUS.

GUS. (2020a). Aktywność ekonomiczna ludności Polski IV kwartał 2019 r. Warszawa: GUS.

GUS. (2020b). Aktywność ekonomiczna ludności Polski I kwartat 2020 r. Warszawa: GUS.

GUS. (2020c). Informacja o rynku pracy w pierwszym kwartale 2020 roku. Warszawa: GUS. Retrieved from www.stat.gov.pl

Jaumotte F. (2003). Female labour force participation: Past trends and main determinants in OECD countries (OECD, Work Paper No 376, December). Retrieved from www.papers.ssrn.com/sol3/ papers.cfm? abstract_id $=2344556$

Korpas, J., (2018). Wpływ zmian prawnych i innych czynników na kształt wypłat zasiłków macierzyńskich. Ubezpieczenia Spoleczne. Teoria i Praktyka, (2), 87-103.

Kotowska, I. E., Sztanderska, U., \& Wóycicka, I. (2007). Między domem a praca: rekomendacje. Warszawa: Scholar.

Kwiatkowska, A. (2016). Działania państwa w zakresie ochrony pracy kobiet w aspekcie urlopu macierzyńskiego. Rynek-Społeczeństwo-Kultura, 3(19).

Lechman, E. (2019). Still 'few, slow and low'? On the female dimension of technology, labour markets and economic activity: Evidence for the period of 1990-2017. Economics and Sociology, 12(1), 11-38. doi:10.14254/2071-789X.2019/12-1/1

Ministerstwo Rodziny, Pracy i Polityki Społecznej. (2017). Informacja o realizacji świadczeń rodzin$n y c h$ w $2016 r$. Warszawa: Ministerstwo Rodziny, Pracy i Polityki Społecznej.

Pal'ová, D., \& Vejačka, M. (2018). Analysis of employment in the EU according to Europe 2020 Strategy targets. Economics and Sociology, 11(3), 96-112. doi:10.14254/2071-789X.2018/11-3/6

Pufal-Struzik, I. (2017). Aktywność zawodowa współczesnych kobiet - trudności w realizacji nowych ról i tradycyjnych obowiązków. Polskie Forum Psychologiczne 22(2), 242-257. doi:10.14656/ PFP20170204 
Qerimi, Q., \& Sergi, B. S. (2017). The nature and the scope of the global economic crisis' impact on employment trends and policies in South East Europe. Journal of International Studies, 10(4), 143-153. doi:10.14254/2071-8330.2017/10-4/11

Raišiena, A., Bagdonienb, J., \& Bilan Y. (2014). Inter-institutional interaction results: The effect of EU programs on the reduction of long-term unemployment. Procedia Economics and Finance, (16), 641-650. doi:10.1016/S2212-5671(14)00852-1

Raport PwC. (2016). Finansowe wsparcie rodzin: awans Polski do czołówki państw UE. Warszawa: PwC.

Rękas, M. (2013). Kobiety-matki i ich powrót na rynek pracy po urodzeniu dziecka w wynikach badań. Studia Ekonomiczne, (161), 122-131.

Rhum C. J. (1998). The economic Consequences of Parental Leave Ma, ndates: lessons from Europe, “The Quarterly Journal of Economics" no 113, pp. 285-317

Sielska, A. (2017). Dyskryminacja instytucjonalna kobiet na polskim rynku pracy. Warszawa: CeDeWu.

Soylu, Ö. B., Çakmak, I., \& Okur, F. (2018). Economic growth and the unemployment issue: Panel data analysis in Eastern European countries. Journal of International Studies, 11(1), 93-107. doi:10.14254/2071-8330.2018/11-1/7

Thevenon O., \& Solaz A. (2013). Labour Market Effects of Parental Leave Policies in OECD Countries, OECD Social, Employment and Migration Working Papers, nr 141, OECD Publishing, 2013 http://dx.doi.org/ 10.1787/5k8xb6hw1wjf-en

Titkow, A. (2003). Szklany sufit. Bariery i ograniczenia kariery kobiet. Warszawa: Instytut Spraw Publicznych.

Turner, J. H. (2012). Struktura teorii socjologicznej. Warszawa: PWN.

United Nations. (2015). The world's woman 2015. Trends and statistics. New York: United Nations. Retrieved from https://unstat.un.org

ZUS. (2019). Raport roczny ZUS 2018. Warszawa: ZUS. Retrieved from https://www.zus.pl

\title{
WYMIAR URLOPU MACIERZYŃSKIEGO ZWIĄZANEGO Z PELNIENIEM OSOBISTEJ OPIEKI NAD DZIECKIEM ORAZ WYSOKOŚĆ ZASILKU JAKO DETERMINANTY AKTYWNOŚCI ZAWODOWEJ KOBIET
}

\begin{abstract}
Streszczenie: Celem artykułu jest próba oceny oddziaływania wymiaru urlopu macierzyńskiego jako podstawy wypłaty zasiłku macierzyńskiego w ramach ubezpieczeń społecznych oraz wysokości zasiłku na aktywność zawodową kobiet $\mathrm{W}$ opracowaniu starano się ocenić zależność pomiędzy wymiarem urlopu macierzyńskiego oraz związanymi z nim wypłatami zasiłku macierzyńskiego a wskaźnikiem zatrudnienia, z drugiej zaś strony, w oparciu o przeprowadzone badania ankietowe, wskazać, czy wydłużenie urlopu macierzyńskiego może ograniczać zatrudnienie kobiet. Opisano aktywność zawodową kobiet, poziom wydatków na zasiłki związane z opieką nad dzieckiem w Polsce i w wybranych krajach Unii Europejskiej. Na podstawie danych statystycznych dokonano próby oceny wpływu wysokości zasiłków macierzyńskich na aktywność zawodową kobiet w oparciu o metodę regresji liniowej. Zaprezentowano także fragmenty własnych badań ankietowych z lat 2013-2020, które sugerują, iż wydłużenie urlopu macierzyńskiego może zniechęcać pracodawców do zatrudniania kobiet, a w konsekwencji prowadzić do wycofania się ich z rynku pracy.
\end{abstract}

Słowa kluczowe: finanse publiczne, zasiłek macierzyński, urlop macierzyński, współczynnik aktywności zawodowej kobiet. 